\title{
JUST PUBLISHED:
}

another in the series of

INTERNATIONAL STUDIES

Committee on International Relations University of Notre Dame

\section{The Fate of East Central Europe: Hopes and Failures of American Foreign Policy}

Edited by Stephen D. Kertesz

Contributors: Alvin M. Bentley, Committee on Foreign Affairs, U. S. House of Representatives; Robert F. Byrnes, MidEuropean Studies Center; Alex N. Dragnich, Vanderbilt University; Ivo Duchacek, City College of New York; Robert H. Ferrell, Indiana University; Gottfried Haberler, Harvard University; Oscar Halecki, Fordham University; Stephen D. Kertesz, University of Notre Dame; Philip E. Mosely, Council on Foreign Relations and Columbia University; $\mathbf{R}$. John Rath, University of Texas; Arvid Schwabe, formerly of the University of Latvia in Riga; Stavro Skendi, Columbia University; Nicolas Spulber, Indiana University; Karl C. Thalheim, Osteuropa Institute, Berlin; Robert Lee Wolff, Harvard 446 pages

University; John B. Wuorinen, Columbia University.

\section{Still available:}

German Protestants Face the Social Question

William O. Shanahan Probable price: $\$ 6.25$

Diplomacy in a Whirlpool: Hungary Between Nazi Germany and Soviet Russia

Stephen D. KeRTesz

Sovief Imperialism: Its Origins and Tactics

Edted by Waldemar Gurian

Pan-Slavism: Its History and Ideology

HaNs KoHN

The Foreign Policy of the British Labour Government: 1945-1951

M. A. Fitzsimons

Christian Democracy in Italy and France

Mario Einaudr and Francois Goguel

Bolshevism: An Introduction to Soviet Communism Waldemar Gurian

Europe Bełween Democracy and Anarchy

Ferdinand A. Hermens

at your bookstore or from

University of Notre Dame Press Notre Dame, Indiana 


\section{THE WESTERN POLITICAL QUARTERLY}

A Regional Journal of National and International Standing. Published by the Institute of Government, University of Utah.

Adopted by the Western, Pacific Northwest, and Southern California Political Science Associations as their official journal.

Subscription, $\$ 5.00$ per year in advance.

Subscriptions, manuscripts, and advertising should be addressed to:

Business Manager

THE WESTERN POLITICAL QUARTERLY

UNIVERSITY OF UTAH

Salt Lake City 12, Utah

\section{PARLIAMENTARY AFFAIRS}

The Quarterly Journal of the Hansard Sociely for Parliamentary Government

\section{SOME RECENT ARTICLES}

The Office of Lord Chancellor....The Rt. Hon. The Viscount Kilmuir, G.C.V.O., Lord High Chancellor of Great Britain The Development of Parliamentary Institutions in Germany since 1945

Parliamentary Government in Italy today Konrad Adenauer

.............. Roy Pryce

Dail Eireann ……................................................. David Hogan

The Legislative Reference Service of Congress.... George B. Galloway Parliament and the Press ............................................ A. E. Musson

Parliamentary Democracy and Poll Democracy............ David Mitrany

The Public Philosophy ......................... John H. MacCallum Scott

The Politics of Admission to Statehood in America......John S. Harris

The Making of the Union of South Africa .............W. F. Gutteridge

The Growth of Parliamentary Government in India, 1919-1950 D. N. Banerjee

Single copies, $\$ 1.25$ Annual subscription, $\$ \mathbf{\$ 4} .50$

The Hansard Society for Parliamentary Government 39, Millbank, London, S.W.1 


\section{Teachers}

FORTY YEARS AGO the idea that knowledge of political parties, the price of electricity and the chance of a graduate's finding a job belonged among the materials of education was a revolutionary notion. Today, school walls are wide open to the problems which stretch beyond the classroom. Since 1914, the editors of The New Republic and its distinguished contributors-such men as Professor John Dewey, Professor Charles A. Beard, Herbert Croly, (or, in 1956, V. O. Key, Wilfred Binkley, Malcolm Moss, Stephen Bailey, Arthur Schlesinger, Jr.) - have been among those who have helped throw open the academic gates to intelligent discussion of the raging controversies of our time. An important part of the weekly New Republic audience has always been composed of teachers and students. This Journal of Opinion is used today for supplementary reading in colleges and schools throughout the country.

If you are a teacher of government, literature, sociology, history or economics, we invite you to consider using The New Republic in your classroom. As in years past, we offer you the opportunity of ordering this magazine at a special classroom rate for bulk orders of 10 or more. Each student's copy costs only 10 cents weekly (one-half the regular newsstand price) if 10 or more are mailed to a single address. Free desk copies are included for each instructor. Orders may be placed for any number of weeks, even for one week only, if desired, or for the entire semester. Copies are mailed from Washington, D. C., on Tuesdays, two days before The New Republic appears on any newsstand, so that your students are assured of receiving the magazine while the news and book reviews are fresh and exciting.

Advance payment is not necessary. You need only notify us how many copies and how many issues you wish. Your bill will be sent later. Mail your order without delay to:

CLASSROOM DEPARTMENT, THE NEW REPUBLIC 1244 19th Street, N.W., Washington 6, D. G. 